\title{
A study on the frequency of excess weight, obesity and metabolic syndrome among university students
}

\author{
Hasan Hüseyin Çama, Fatma Karasub \\ a Dr. Öğr. Ü. Kilis 7 Aralık U., Yusuf Şerefoğlu Health Science Faculty, Nursing Department, Kilis, Turkey \\ b Dr. Öğr. Ü. Kilis 7 Aralık U., Yusuf Şerefoğlu Health Science Faculty, Nursing Department, Kilis, Turkey
}

\begin{abstract}
Objective: The aim of this study was to assess the frequency of excess weight, obesity and other metabolic syndrome components among university students. Methods: This cross-sectional study included a total of 357 university students. The socioeconomic data, lifestyle, and cardiovascular disease risk factors were filled out using a questionnaire. The clinical screenings included measurement of blood pressure and determination of fasting lipid and glucose concentrations. T-test, Pearson Chi-Square and Fisher's Exact Test were used for statistical analysis. Results: The percentage of overweight or obese individuals was $25.9 \%$ in university students. The metabolic syndrome (MetS) frequency as per the NCEP ATP III criteria was $2.4 \%$ $(\mathrm{n}=7)$. The risk of developing MetS is high among those who smoke and male university students. There were significant correlations between body mass index and systolic blood pressure, diastolic blood pressure, total cholesterol, HDL cholesterol and triglycerides levels. Conclusion: Our findings provide evidence for the high frequency of excess weight and obesity in university students. The cardiovascular disease risk factors among overweight and obese students were significantly higher than normal weight students. Lifestyle modifications such as increased dietary changes and physical activity can be helpful changes in MetS criteria.
\end{abstract}

Keywords: Obesity, metabolic syndrome, university, student

Corresponding Author: Hasan Hüseyin Çam Kilis 7 Aralık U., Yusuf Şerefoğlu Health Science Faculty, Nursing Department, Kilis, Turkey E-mail: cam hasanhuseyin@hotmail.com

Copyright holder Turkish Journal of Public Health

This work is licensed under a Creative Commons Attribution-NonCommercial 4.0 International License. (cc) EY-No This is an open Access article which can be used if cited properly. 


\title{
Üniversite öğrencilerinde fazla kiloluluk, obezite ve metabolik sendrom sıklığı üzerine bir çalışma
}

Öz

\begin{abstract}
Amaç: Bu çalışmanın amacı, üniversite öğrencileri arasında fazla kiloluluk, obezite ve diğer metabolik sendrom bileşenlerinin sıklığını değerlendirmektir. Yöntem: Kesitsel araştırma tasarımı kullanılarak yapılan bu çalışmaya toplam 357 üniversite öğrencisi dâhil edildi. Sosyoekonomik, yaşam tarzı ve kardiyovasküler hastalık risk faktörleri ile ilgili veriler anket formu doldurularak toplandı. Klinik taramalar için kan basıncını ölçümü, açlık lipit ve glikoz konsantrasyonları belirlendi. İstatistiksel analizler için T-testi, Pearson Ki-Kare ve Fisher's Exact Testi kullanıldı. Bulgular: Üniversite öğrencilerinde fazla kiloluluk ve obezite sıklı̆g $1 \% 25,9$ olarak belirlendi. NCEP ATP III kriterlerine göre metabolik sendrom (MetS) sıklı̆̆ \%2,4 (n = 7) idi. MetS gelişme riski, sigara içenler ve erkek üniversite öğrencileri arasında yüksek olarak tespit edildi. Beden kitle indeksi ile sistolik kan basıncl, diyastolik kan basıncl, total kolesterol, HDL kolesterol ve trigliserid düzeyleri arasında anlamlı bir ilişki bulundu. Sonuç: Bulgularımız, üniversite öğrencilerinde fazla kiloluluk ve obezite sıklığının yüksek oranda olduğuna dair kanıtlar sağlamaktadır. Fazla kilolu ve obez öğrencilerde kardiyovasküler hastalık risk faktörleri normal kilolu öğrencilerden anlamlı derecede daha yüksek idi. Artan fiziksel aktivite ve diyet gibi yaşam tarzı değişiklikleri MetS kriterlerinde yararlı değişiklikler yapabilir.
\end{abstract}

Anahtar Kelimeler: Obezite, metabolik sendrom, üniversite, öğrenci

\section{Introduction}

Being overweight or obese is defined as having abnormal or excessive fat accumulation that presents a risk to health. ${ }^{1}$ Obesity is a complex condition, one with serious social and psychological dimensions, that affects virtually all age and socioeconomic groups and threatens to overwhelm both developed and developing countries. ${ }^{2}$ In the 12 year long Multinational Monitoring of Trends and Determinants in Cardiovascular Disease (MONICA) study which is performed in Asia, Africa and 6 different regions of Europe, it was announced that obesity frequency showed an increase of between $10-30 \%$ within 10 years. $^{3}$ According to Turkish Epidemiology Survey of Diabetes, Hypertension, Obesity and Endocrine Disease II Study (TURDEP-II) ('TURDEP-II' included 26,499 randomly sampled adults aged $\geq 20$ years) obesity frequency (BMI $30 \geq \mathrm{kg} / \mathrm{m}^{2}$ ) was $31.2 \%$ (female $44.2 \%$ and male $27.3 \%$ ). ${ }^{4}$ Studies show that overweight or obese prevalence in university students is 17.1 to $27.6 \% .^{5-7}$

Overweight and obesity are major risk factors for several chronic diseases, including diabetes, cardiovascular diseases and cancer. ${ }^{1}$ Cardiovascular diseases (CVDs) are the number one cause of death globally: more people die annually from CVDs than from any other cause. An estimated 17.7 million people died from CVDs in 2015, representing $31 \%$ of all global deaths. Of these deaths, an estimated 7.4 million were due to coronary heart disease and 6.7 million were due to stroke. ${ }^{8}$ CVDs have multiple risk factors, the most important being dyslipidemias, high blood pressure (BP), smoking, excess weight and obesity, low physical activity, diabetes, and metabolic syndrome (MetS). Almost all of them are modifiable, suggesting that most CVDs are preventable. ${ }^{9}$ The MetS is a cluster of the most dangerous heart attack risk factors: diabetes and raised fasting plasma glucose, abdominal obesity, high cholesterol and high blood pressure. ${ }^{10}$ Globally, MetS is common, 
with a reported age-adjusted frequency of $22.9 \%$ in the US and $31.2 \%$ in Venezuela, and the frequency in Korea increased from $24.9 \%$ to 31.2 during 1998-2007.11 The frequency of MetS in Turkey varies from $23.7 \%$ to $32.2 \%$ for males over 20 years old and from $38.6 \%$ to $45.0 \%$ for females. ${ }^{12}$ The prevalence of metabolic syndrome in university students according to the literature varies from 1.9 to $14.2 \% .6,7,11,13-16$

Early detection of MetS is critical for the commencement of directed interventions leading to reduction in the risk of progression to MetS, coronary heart disease and diabetes. The risk factors for MetS include sedentary lifestyle, central obesity, an elevated Body Mass Index (BMI), poor dietary habits and lack of physical exercise. Each of these factors has been shown to cause enhanced predisposition towards MetS when they occur at an early age. ${ }^{13}$ It is important to develop good health habits and identify ways to prevent metabolic syndrome among university students as they transition from adolescence to adulthood. ${ }^{17}$

Limited number of studies have been performed on youth age obesity and accompanying cardiovascular risk factors in the developing world. For a better understanding on the issue and more efficient programs for worldwide prevention of CVDs mortality, more ethnic-specific studies are needed. Therefore, we conducted this study to determine the frequency of excess weight, obesity and MetS components among university students and identify potential risk factors that can be used for the prevention and management of MetS in young adults.

\section{Material and Methods}

\section{Study design}

This cross-sectional study was carried out at a total of 357 university students $(139$ males (38.9\%) and 218 females (61.1\%) ) enrolled in the Faculty of Health Sciences, Kilis, Turkey, from April 2017 to June 2017, and comprised undergraduate university students aged between 18 and 27 years. The participation rate was $81.23 \% \quad(290$ students).

\section{Method/study procedure}

The research project has been approved by the Gaziantep University Clinical Research Ethics Board (Reference Number: 2017/35). Participants were informed concerning the research purposes and the methodology to be used and signed the Informed Consent Form. The socioeconomic data (age, gender, living with family, residential status, birth order, father's education and mother's education) lifestyle (smoking, drinking and exercise) and cardiovascular disease risk factors were filled out using a questionnaire. Anthropometric measures and blood chemistries were obtained. The clinical screenings included measurement of blood pressure (BP) and specification of fasting lipid and glucose concentrations.

Biochemical measures: Blood sampling was conducted early in the morning after a 12-h overnight fast. Samples were transported to the clinic's laboratory within 2 hours of collection and serum was separated by centrifugation. Serum levels of fasting glucose (FG), total cholesterol (TC), HDL cholesterol (HDL-C), LDL cholesterol (LDLC), triglycerides (TG) were determined.

Anthropomorphic measurements: Extra fine digital scales with F.BOSH size were used for measurements. The device is designed to measure weight $(\mathrm{kg})$, height $(\mathrm{cm})$ and BMI with infrared and ultrasonic technology (capacity: $150 \mathrm{~kg}$, sensitivity: $0.1 \mathrm{~kg}$ ). Body Mass Index (BMI) is a simple index of weight-for-height that is usually used to classify underweight, overweight and obesity in adults. It is defined as the weight in kilograms divided by the square of the height in metres $\left(\mathrm{kg} / \mathrm{m}^{2}\right)$. The International Classification of adult underweight, overweight and obesity according to BMI is: underweight < 18.50; normal range 18.5024.99; overweight 25.00-29.99; obese $\geq 30.00 .18$

Blood Pressure Measurements: Blood pressure (BP) was measured after a 5-min seated resting period. A trained nurse student measured each subject's resting BP. The width of the cuff was placed at the highest possible part of the right arm. BP was conducted in thrice, with a 5-min interval between measurements. 
Definition of Metabolic Syndrome (MetS): In the current study, cardiometabolic risk factors were defined as the five risk factors following the MetS definition. The National Cholesterol Education Program's Adult Treatment Panel III (NCEP ATP III) definitions for MetS were applied. MetS was defined as including any 3 of the following: (1) Abdominal obesity (If BMI is $>30 \mathrm{~kg} / \mathrm{m}^{2}$, central obesity can be assumed and waist circumference does not need to be measured) waist circumference male $>102$ $\mathrm{cm}$, female $>88 \mathrm{~cm}$; (2) triglycerides $\geq 150$ $\mathrm{mg} / \mathrm{dL}$; (3) HDL cholesterol male $<40$ $\mathrm{mg} / \mathrm{dL}$, female $<50 \mathrm{mg} / \mathrm{dL}$; (4) BP $\geq 130 / \geq$ $85 \mathrm{mmHg}$; (5) fasting glucose $\geq 110$ $\mathrm{mg} / \mathrm{dL} \cdot{ }^{10,19}$

\section{Statistical analyses}

SPSS software version 16.0 was used for analysis. Collected data were described by frequencies and percentages. T-test, Person Chi-Square and Fisher's Exact Test were used for statistical analysis. The level of statistical significance was established at $\mathrm{p}<0.05$.

\section{Results}

Table 1 demonstrates the characteristics of university students according to the number of MetS components, as a function of the variables studied. The sample consisted of 290 university students, of whom $66.9 \%$ were female, with a mean age of $21.00 \pm 1.69$ years old, of whom $83.4 \%$ were in the age range between 17 and 22 years old, with the following profile: $16.6 \%$ were living with their family; a large number (75.5\%) were from urban areas; $33.4 \%$ were born as the first child; paternal and maternal education secondary school and under with $69.3 \%$ and $90.3 \%$, respectively. A family history of cardiovascular disease was reported to be present in $22.1 \%$ of the students. The frequencies of smoking, drinking and sedentary lifestyle were $16.2 \%, 14.1 \%$ and $41.4 \%$, respectively. In relation to the combination of the demographic variables and lifestyle variables with the number of components of MetS, it is ascertained that there was a statistically significant association with gender and smoking. The risk of MetS is high among those who smoke and male university students $(\mathrm{p}<0.05)$.

Table 2 demonstrates the anthropometric data of BMI and the other components of MetS. According to nutritional status, $3.8 \%(\mathrm{n}=11)$ of participants were classified as underweight, $70.3 \%(\mathrm{n}=204)$ normal weight, $19.3 \%(\mathrm{n}=$ 56) were overweight and $6.6 \%(n=19)$ obese, according to the World Health Organization classification. The frequency of overweight or obesity (BMI $\geq 25.0 \mathrm{~kg} / \mathrm{m}^{2}$ ) was $25.9 \%$ in university students. $1.4 \%$ had a high fasting glucose levels; $2.1 \%$ had high systolic or diastolic blood pressures levels; $7.9 \%$ had higher total cholesterol levels; $29.0 \%$ had low HDL cholesterol levels; 23.4\% had high LDL cholesterol levels and $11.0 \%$ had high triglyceride levels.

Table 3 demonstrates the anthropometric data and other components of MetS and their relationship to gender. The mean of body mass index, systolic blood pressure, diastolic blood pressure and triglycerides were higher in males than females, while the mean HDL cholesterol was higher in females than males $(\mathrm{p}<0.05)$.

The relationships between fasting glucose, blood pressure, diastolic blood pressure, total cholesterol, HDL cholesterol, LDL cholesterol and triglycerides, and obesity indices treated as categorical data are presented in Table 4. There were significant correlations between body mass index and systolic blood pressure, diastolic blood pressure, total cholesterol, LDL cholesterol and triglycerides levels. Mean levels of systolic blood pressure, diastolic blood pressure, total cholesterol, LDL cholesterol and triglycerides in overweight or obese (BMI $\geq 25.00 \mathrm{~kg} / \mathrm{m}^{2}$ ) students were significantly higher than the healthy weight $\left(\mathrm{BMI}<25.00 \mathrm{~kg} / \mathrm{m}^{2}\right)$ group.

Table 5 presents the frequency of MetS. According to the criteria of NCEP-ATP III, $62.4 \%$ of the sample did not present any component of MetS, while 35.2\% presented at least two components, and $2.4 \%$ had three or more. The frequency of MetS was significantly higher in males than in females $(6.2 \%$ and $0.5 \%$, respectively) $(\mathrm{p}<0.05)$. 
Table 1. Relationship of demographic variables and lifestyle variables with components for MetS, among university students

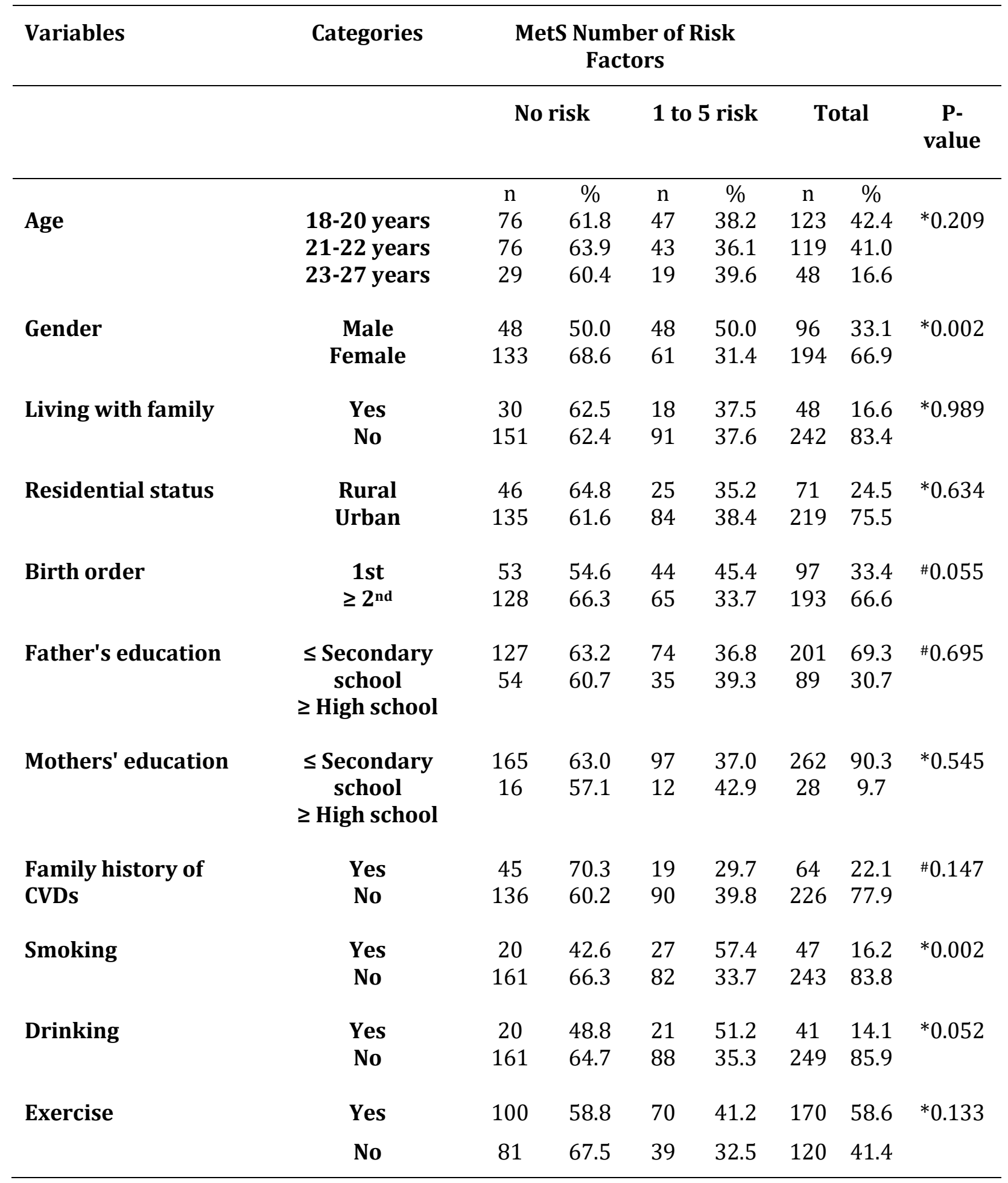

*Pearson Chi-Square \#Fisher's Exact Test 
Table 2. Anthropometric data and components of MetS among university students

\begin{tabular}{|c|c|c|c|c|c|}
\hline Variable & Categories & $\mathbf{n}$ & $\%$ & Min - Max & Mean \pm SD $^{*}$ \\
\hline \multirow[t]{4}{*}{ BMI } & Underweight $\left(<18.50 \mathrm{~kg} / \mathrm{m}^{2}\right)$ & 11 & 3.8 & $16.1-46.00$ & $23.57 \pm 3.91$ \\
\hline & Normal range $\left(18.50-24.99 \mathrm{~kg} / \mathrm{m}^{2}\right)$ & 204 & 70.3 & & \\
\hline & Overweight $\left(25.00-29.99 \mathrm{~kg} / \mathrm{m}^{2}\right)$ & 56 & 19.3 & & \\
\hline & Obese $\left(\geq 30.00 \mathrm{~kg} / \mathrm{m}^{2}\right)$ & 19 & 6.6 & & \\
\hline \multirow[t]{2}{*}{ FG } & Normal $(<110 \mathrm{mg} / \mathrm{dL})$ & 286 & 98.6 & $54.00-$ & $85.57 \pm 9.70$ \\
\hline & High $(\geq 110 \mathrm{mg} / \mathrm{dL})$ & 4 & 1.4 & 127.00 & \\
\hline \multirow[t]{2}{*}{ SBP } & Normal (< 85 mmHg) & 284 & 97.9 & $86.67-146.67$ & $109.97 \pm 10.47$ \\
\hline & High ( $\geq 85 \mathrm{mmHg}$ ) & 6 & 2.1 & & \\
\hline \multirow[t]{2}{*}{ DBP } & Normal (<130 mmHg) & 284 & 97.9 & $56.67-96.67$ & $68.59 \pm 6.87$ \\
\hline & High $(\geq 130 \mathrm{mmHg})$ & 6 & 2.1 & & \\
\hline \multirow[t]{2}{*}{ TC } & Normal $(<200 \mathrm{mg} / \mathrm{dL})$ & 267 & 92.1 & $26.90-255.00$ & $152.95 \pm$ \\
\hline & High $(\geq 200 \mathrm{mg} / \mathrm{dL})$ & 23 & 7.9 & & 31.39 \\
\hline \multirow[t]{3}{*}{ HDL-C } & Normal (Male: >40. Female: > 50 & 206 & 71.0 & $23.70-106.20$ & $53.65 \pm 14.19$ \\
\hline & $\mathrm{mg} / \mathrm{dL})$ & 84 & 29.0 & & \\
\hline & $\begin{array}{c}\text { Low (Male: }<\text { 40. Female: }<50 \\
\mathrm{mg} / \mathrm{dL})\end{array}$ & & & & \\
\hline \multirow[t]{2}{*}{ LDL-C } & Normal $(<100 \mathrm{mg} / \mathrm{dL})$ & 222 & 76.6 & $26.90-163.30$ & $82.51 \pm 25.97$ \\
\hline & High $(\geq 100 \mathrm{mg} / \mathrm{dL})$ & 68 & 23.4 & & \\
\hline \multirow[t]{2}{*}{ TG } & Normal $(<150 \mathrm{mg} / \mathrm{dL})$ & 258 & 89.0 & $11.40-313.00$ & $93.54 \pm 46.34$ \\
\hline & High ( $\geq 150$ mg/dL) & 32 & 11.0 & & \\
\hline
\end{tabular}

BMI= Body Mass Index; FG = Fasting Glucose; SBP= Systolic Blood Pressure; DBP= Diastolic Blood Pressure; $\mathrm{TC}=$ Total Cholesterol; HDL-C= HDL Cholesterol; LSL-C= LDL Cholesterol; TG= Triglycerides; SD= Standard Deviation.

Table 3. Anthropometric data and other components of MetS and their relationship to gender

\begin{tabular}{lccc}
\hline Variable & $\begin{array}{c}\text { Female }(\mathbf{n}=\mathbf{1 9 4}) \mathbf{( 6 6 . 9 \% )} \\
\text { Mean } \pm \text { SD }\end{array}$ & $\begin{array}{c}\text { Male }(\mathbf{n}=\mathbf{9 6}) \mathbf{( 3 3 . 1 \% )} \\
\text { Mean } \pm \text { SD }\end{array}$ & P-value* \\
\hline BMI (kg/m $\mathbf{~})$ & $23.17 \pm 3.71$ & $24.39 \pm 4.20$ & 0.013 \\
FG (mg/dL) & $87.12 \pm 10.13$ & $84.81 \pm 9.42$ & 0.056 \\
SBP (mm Hg) & $107.09 \pm 8.98$ & $115.79 \pm 10.88$ & 0.001 \\
DBP (mm Hg) & $67.30 \pm 6.05$ & $71.21 \pm 7.69$ & 0.001 \\
TC (mg/dL) & $153.72 \pm 31.11$ & $151.36 \pm 32.05$ & 0.553 \\
HDL-C (mg/dL) & $58.77 \pm 13.24$ & $43.31 \pm 9.74$ & 0.000 \\
LDL-C (mg/dL) & $81.10 \pm 24.78$ & $85.38 \pm 28.14$ & 0.187 \\
TG (mg/dL) & $83.89 \pm 35.95$ & $113.06 \pm 57.72$ & 0.000 \\
\hline
\end{tabular}

BMI= Body Mass Index; FG = Fasting Glucose; $\mathrm{SBP}=$ Systolic Blood Pressure; DBP= Diastolic Blood Pressure; $\mathrm{TC}=$ Total Cholesterol; HDL-C $=$ HDL Cholesterol; LSL-C= LDL Cholesterol; TG= Triglycerides; $\mathrm{SD}=$ Standard Deviation. *Independent-Samples T-Test 
Table 4. Association weight status with components of MetS among university students

\begin{tabular}{lccc}
\hline Variable & \multicolumn{1}{c}{ Body Mass Index (BMI) $\left(\mathbf{k g} / \mathbf{m}^{2}\right)$ ) } \\
\hline & $\begin{array}{l}\text { BMI }<\text { 25.00 (n = 215) } \\
\text { Healthy Weight }\end{array}$ & $\begin{array}{c}\text { BMI } \geq 25.00(\mathbf{n}=75) \\
\text { Overweight or Obese }\end{array}$ & \\
\hline Mean \pm SD & Mean \pm SD & P-value* \\
\hline FG(mg/dL) & $85.24 \pm 9.58$ & $86.54 \pm 10.05$ & 0.320 \\
SBP (mmHg) & $108.60 \pm 9.75$ & $113.91 \pm 11.48$ & 0.000 \\
DBP (mmHg) & $67.55 \pm 6.28$ & $71.60 \pm 7.63$ & 0.000 \\
TC (mg/dL) & $148.61 \pm 29.91$ & $165.39 \pm 32.39$ & 0.000 \\
HDL-C (mg/dL) & $54.29 \pm 14.01$ & $51.83 \pm 14.64$ & 0.197 \\
LDL-C (mg/dL) & $79.51 \pm 24.37$ & $91.13 \pm 28.54$ & 0.001 \\
TG (mg/dL) & $86.52 \pm 38.79$ & $113.66 \pm 59.00$ & 0.000 \\
\hline
\end{tabular}

BMI= Body Mass Index; FG = Fasting Glucose; SBP= Systolic Blood Pressure; DBP= Diastolic Blood Pressure; $\mathrm{TC}=$ Total Cholesterol; HDL-C $=$ HDL Cholesterol; LSL-C = LDL Cholesterol; TG= Triglycerides; $\mathrm{SD}=$ Standard Deviation. *Independent-Samples T-Test

Table 5. Frequency of number of risk factors of the MetS

\begin{tabular}{|c|c|c|c|c|c|c|c|}
\hline Variable & \multicolumn{2}{|c|}{$\begin{array}{c}\text { Female } \\
(n=194)\end{array}$} & \multicolumn{2}{|c|}{$\begin{array}{c}\text { Male } \\
(n=96)\end{array}$} & \multicolumn{2}{|c|}{ Total } & \multirow[t]{2}{*}{ P-value* } \\
\hline MetS Number of Risk Factors & $\mathbf{n}$ & $\%$ & $\mathbf{n}$ & $\%$ & $\mathbf{n}$ & $\%$ & \\
\hline No risk factor & 133 & 68.6 & 48 & 50.0 & 181 & 62.4 & \\
\hline 1 to 2 risk factors & 60 & 30.9 & 42 & 43.8 & 102 & 35.2 & $<0.001$ \\
\hline 3 to 5 risk factors & 1 & 0.5 & 6 & 6.2 & 7 & 2.4 & \\
\hline
\end{tabular}

*Pearson Chi-Square 


\section{Discussion}

In our survey, a comparatively high percentage of university students were overweight or obese (BMI $\geq 25 \mathrm{~kg} / \mathrm{m}^{2}$ ) (25.9\%). In a study conducted by Rashidi et al. among medical university students in Iran, the frequency of overweight or obesity were found to be $17.1 \% .^{5}$ Silva et al. in a Brazilian study reported that $20.4 \%$ of university students were overweight or obesity. ${ }^{6}$ In another study, Martínez-Torres et al. among collegiate students in Colombia, the frequency of overweight or obesity were found to be $27.6 \% .^{7}$ The results of this study put forward that there is a high frequency of overweight/obesity in this group of university students.

MetS is diagnosed with a constellation of clinical and anthropometrical tests. The present study was planned to detect the frequency of MetS, its components and predictors in university students. The MetS frequency in the current study is the lower end of the range, 1.9 to $14.2 \%$, found in other studies. The frequency of this study was higher than that of Mbugua et al. (2017) (1.9\%), and lower than of Silva et al. (2014) (3.5\%), Smith et al. (2009) (4\%), Shin et al. (2015) (4\%), MartínezTorres et al. (2017) (6\%), Topè et al. (2013) (12\%), Shahzad et al. (2017) (14.2\%).6,7,11,1316 The variation in the frequency of MetS can be connected to the difference in age groups of the study subjects and the various definitions used and ethnological variations among study groups.

In the present study we found that, compared to students with normal weight, overweight and obese students have a higher frequency of many components of the MetS, including systolic blood pressure, diastolic blood pressure, total cholesterol, LDL cholesterol and triglycerides. Similarly, Topè et al., in a US study of among college students found that the approximately $40 \%$ of obese subjects had three or more criteria for MetS, a much higher frequency than found among subjects in the normal or overweight categories $\left(2.7 \%\right.$ and $2.0 \%$ respectively). ${ }^{15}$ In another study, Kandula et al. reported that the MetS is only found to be prevalent in those who are overweight and obese.20 Another study conducted in Colombia,
Feliciano-Alfonso et al. found that body mass index was associated with significant increases in blood pressure, LDL cholesterol and plasma triglyceride levels. ${ }^{21}$

In present study, we found the frequency of MetS to be higher among males compared to females ( $6.2 \%$ versus $0.5 \%)$, which is statistically significant. There are substantial number of studies demonstrating significant differences in frequency of MetS among males and females. Our results are consistent with previous studies.6,7,22 Silva et al. in their study found higher frequency of MetS in males than in females $(5.9 \%$ versus 2.2\%). ${ }^{6}$ Martínez-Torres et al. reported that the frequency of MetS was three times higher in males than in females $(9.1 \%$ versus 3.0\%). ${ }^{7}$ Turchiano et al's New York study also demonstrated that males tended to have higher rates of MetS than females. ${ }^{22} \mathrm{~A}$ higher frequency in males might be related to higher rates of obesity and lifestyle habits like smoking. The findings of this study differ from a study conducted by Rashidi et al. where the female frequency of MetS was higher than the male. 5 In another study, Olfert et al. also demonstrated that the frequency of MetS did not differentiate between males and females. ${ }^{23}$ Hence, additional studies of university students with larger sample sizes are required to better clarify this relationship.

The frequency of smoking among the study population was $16.2 \%$. There is a significant association between smoking and MetS. Smokers are almost twice as likely to have at least 1 metabolic risk factor than non-smokers. A national nourishment examination survey in USA reported an enhancement in risk of development of MetS among females (OR, 1.8; 95\% CI: 1.2 - 2.6) and males (OR, 1.5; 95\% CI: $1.1-2.2$ ) who were present smokers compared with those who never smoked. ${ }^{24}$ Similarly a study by Kandula et al. conducted among students of a medical college in India showed the risk of having MetS among smokers is 6 times than among non-smokers. ${ }^{20}$ Contrary to our findings, in a study conducted by Shin et al., who also found that smoking was not associated with MetS.11 Different definitions of metabolic syndrome and individual baseline information of the study population 
might lead to inconsistent results on this issue.

Our study has several limitations. Firstly, the main limitations of the present study are the characteristics inherent in a cross-sectional study, i.e., the associations between MetS and variables cannot be interpreted as causal associations. Secondly, the generalizability is restricted by the relatively small sample size and our convenience sampling method. In our analyses, we assessed risk factors for meeting 1 or more of the metabolic syndrome criterion owing to our low number of subjects with metabolic syndrome. Thirdly, one should be cautious when explaining the differences between the sexes due to the low sampling of males in our study. Moreover, studies with university students are operationally more complex, mainly with respect to the collection of blood tests, as numerous had situations or worked until late at night and had to eat - and hence did not comply with the 12 hours of fasting. In the future, longitudinal studies are needed to determine the causal relationship between these risk factors and MetS in university students.

In summary, there is a high frequency of excess weight or obesity among university students. A substantial number of overweight/obese students have MetS. The frequency of MetS increases with increased BMI. MetS is highly prevalent among males compared to females. A significant association is found between smoking and MetS. The results demonstrate the need for incentivizing healthy choices, with an emphasis on behavioral and lifestyle changes, particularly diet, physical activity, and smoking. Appropriate management of tobacco use can help reduce the risk of MetS. Early screening, recognition and lifestyle interventions can help reduce the morbidity of cardiovascular diseases. It is up to government agencies and health professionals to discuss the issue and the application of public health policies with the aim of contributing to excess weight reduction and encourage individuals to practice healthy lifestyle habits. To address the issue of expanding prevalence of obesity and possibly dangerous results of metabolic syndrome in university students, more investigations will be required, focusing on the reasons for the increase of overweight/ obesity in children, and interventions so as to decrease the epidemics of overweight/obesity and metabolic syndrome within the population.

\section{References}

1. WHO. Obesity. Available at: http://www.who.int/topics/obesity/en/ . Accessed July 3, 2017.

2. WHO. Controlling the global obesity epidemic. Available at: http://www.who.int/nutrition/topics/o besity/en/. Accessed July 12, 2017.

3. The Ministry of Health of Turkey. Current Situation of Obesity in the World and Europe. Available at: http://beslenme.gov.tr/index.php?lang= en\&page $=39$. Accessed July 5, 2017.

4. Satman I and TURDEP-II Study group. Türkiye Diyabet, Hipertansiyon, Obezite ve Endokrinolojik Hastaliklar Prevalans Çalişmasi-II (TURDEP-II) Sonuçlari. Available at: http://www.turkendokrin.org/files/file/ TURDEP_II_2011.pdf. Accessed July 12, 2017.

5. Rashidi AA, Parastouei K, Shahaboddin ME. Metabolic syndrome among medical university students in Kashan, Iran. Scientific Research and Essays 2012; 7(41):3549-3553.

6. Silva ARV da, Sousa LSN de, Rocha $T$ de $S$, Cortez RMA, Macêdo LG do N, Almeida PC de. Prevalence of metabolic components in university students. Rev Lat Am Enfermagem 2014; 22(6): 10411047.

7. Martínez-Torres J, Correa-Bautista JE, González-Ruíz K, Vivas A, Triana-Reina HR, Prieto-Benavidez DH, Carrillo HA, Ramos-Sepúlveda JA, Villa-González E, García-Hermoso A, Ramírez-Vélez R. A Cross-Sectional Study of the Prevalence of Metabolic Syndrome and Associated Factors in Colombian Collegiate Students: The FUPRECOL-Adults Study. Int J Environ Res Public Health 2017; 14(3). pii: E233.

8. WHO. Cardiovascular diseases (CVDs). Available 
http://www.who.int/mediacentre/facts heets/fs317/en/. Accessed July 3, 2017.

9. Reiner Ž, Sonicki Z, Tedeschi-Reiner E. The perception and knowledge of cardiovascular risk factors among medical students. Croat Med J 2012; 53(3):278-84.

10. IDF. The IDF consensus worldwide definition of the METABOLIC SYNDROME. Belgium: International Diabetes Federation, 2006.

11. Shin MK, Won J, Yi H. Prevalence of Metabolic Syndrome in University Students in Korea. Indian Journal of Science and Technology 2015; 8(16):1-7.

12. Republic of Turkey Ministry of Health. Chronic Diseases and Risk Factors Survey in Turkey. Ankara: Republic of Turkey Ministry of Health, 2013.

13. Mbugua SM, Kimani ST, Munyoki G. Metabolic syndrome and its components among university students in Kenya. BMC Public Health 2017; 17(1):909.

14. Smith C, Essop MF. Gender differences in metabolic risk factor prevalence in a South African student population. Cardiovasc J Afr 2009; 20(3):178-182.

15. Topè AM, Rogers PF. Metabolic syndrome among students attending a historically black college: prevalence and gender differences. Diabetol Metab Syndr 2013; 5:2.

16. Shahzad F, Ishaque A, Noman ul Haq. Frequency and predictors of metabolic syndrome in adolescents /first year medical students of a public sector medical college Quetta, Pakistan. J Pak Med Assoc 2017; 67(5):752-755.

17. Mee-Kyung S, Jongsoon W, Hyeryeon $Y$. Prevalence of Metabolic Syndrome in University Students in Korea. Indian Journal of Science and Technology 2015; 8(16):1-7.

18. WHO. BMI classification. Available at: http://apps.who.int/bmi/index.jsp?intro Page=intro_3.html. Accessed July 6, 2017.

19. National Institutes of Health. National Cholesterol Education Program. ATP III Guidelines At-A-Glance Quick Desk Reference. Available at: https://www.nhlbi.nih.gov/files/docs/g uidelines/atglance.pdf. Accessed July 3, 2017.
20. Kandula SGNSV, T. V. D. SS, Kongara S, Arepalli SK. A study on the prevalence of obesity and metabolic syndrome among students of a medical college. Int J Res Med Sci 2017; 5(6):2331-2337.

21. Feliciano-Alfonso JE, Mendivil CO, Ariza ID, Pérez CE. Cardiovascular risk factors and metabolic syndrome in a population of young students from the National University of Colombia. Rev Assoc Med Bras (1992) 2010; 56(3):293-298.

22. Turchiano M, Sweat V, Fierman A, Convit A. Obesity, metabolic syndrome, and insulin resistance in urban high school students of minority race/ethnicity. Arch Pediatr Adolesc Med 2012; 166(11):1030-1036.

23. Olfert MD, Dent A, Wattick RA. Metabolic Syndrome Prevalence in Students Attending West Virginia University. J Clin Med 2018; 7(12). pii: E487.

24. Balhara YP. Tobacco and metabolic syndrome. Indian J Endocrinol Metab 2012; 16(1):81-87.

25. 